dida também como abordagem explicativa e descritiva, destaca a Teoria da Burocracia, Estruturalista e Comportamentalista. As abordagens do Desenvolvimento Organizacional, Sistêmica e Contingencial mereceram destaque à parte.

O caminho percorrido pelo autor ao descrever as Teorias da Administração não é linear, pois no transcorrer da exposição vai mostrando como gradativamente os enfoques vão deixando de ser práticos e imediatos e tornando-se modelos mais elaborados que contemplam a organização em toda sua complexidade. Ao referir-se às fronteiras da Administração, o autor passa rapidamente por algumas questões que complementam o entendimento da obra, como por exemplo a necessidade de revisão do modelo mecanicista de tomada de decisão, a tecnoburocracia, a informação e a ideologia.

A leitura da obra é fluente, o humor em algumas passagens facilita a introdução do leitor novato ao tema que, pode ser muito maçante, $\mathrm{co}$ mo é o caso das várias obras de introdução à Administração. Em algumas passagens, contudo, a obra carece de uma contextualização histórica mais precisa das origens da gerência, principalmente no que tange à questão da degradação do trabalho e do capitalismo industrial que, a nosso ver, enriqueceria a percepção do fundo ideológico e de visão do homem que existe por trás das Teorias da Administração. Sem dúvida estas observações não desmerecem a obra que introduz muito bem o tema aos interessados em saber, afinal, o que é Administração.

\title{
TERCEIRIZAÇÃO PASSO A PASSO. O CAMINHO PARA A ADMINISTRAÇÃO PÚBLICA E PRIVADA
}

$\mathbf{0}$ objetivo do livro é apresentar uma reflexão sobre a prática da terceirização nas administrações pública e privada. Pode-se dizer que esta publicação é uma continuação do livro de Jerônimo Souto Leiria, Terceirização - Uma Alternativa da Flexibilidade Empresarial lançado em 1991, foi pioneiro ao abordar o tema no Brasil e tratou o assunto de maneira conceitual e prática. É importante destacar, inicialmente, que este livro dentro do espectro de mudanças na gestão empresarial parte de preceitos legais e procedimentos jurídico-administrativos - deve-se observar que os autores são bacharéis em Direito - permeando com depoimentos de pessoas envolvidas no processo de terceirização.
$\mathrm{O}$ fenômeno do desmonte da estrutura organizacional clássica é observado em todo o mundo já há algum tempo e ganha velocidade, recentemente, com o recrudescimento da competitividade mundial ou das crises econômicas. Nesse contexto e atendendo a necessidades vitais como o aumento de produtividade ou redução de custos que surge a terceirização - contratação de parceiros para executar quaisquer tarefas que não sejam a verdadeira vocação da empresa.

Nos capítulos iniciais $\left(1^{\circ}\right.$ e $\left.2^{\circ}\right)$, são colocados os conceitos e princípios que balizam a terceirização, como prática de administração empresarial, que enfatiza a flexibilidade e agilidade, atendendo para a relação de parceria 
que se estabelece. A terceirização é uma técnica administrativa que se consolidou nos EUA e Japão, tendo sido introduzida no Brasil pelas fábricas de automóveis que adquiriam as peças de um sem-número de outras empresas.

A relação de parceria pressupõe que ambos os lados se capacitem. É importante que o contratante, não apenas pelo desejo momentâneo de baixar custos, desenvolva um plano global de terceirização na empresa, criando espaço para formar uma nova cultura, a cultura da real parceria. Antes da terceirização de cada atividade, deve ser realizada uma profunda análise dos custos diretos e indiretos. O mais lógico e estratégico é a empresa terceirizar inicial e gradualmente todas as atividades transferíveis a especialistas, concentrando integralmente a sua energia em sua verdadeira vocação.

O terceiro capítulo, destaca a problemática da terceirização na administração pública, cujo primeiro desafio é o princípio da legabilidade - ao Estado só é permitido fazer aquilo que a lei prevê, portanto, o administrador público só pode fazer o que a lei permite. A propósito, é necessário lembrar que uma das características da administração pública brasileira é sua pesada regulamentação jurídicoadministrativa, cuja complexidade torna o aparelho administrativo ineficiente e translúcido. Os autores colocam a questão: é possível a terceirização na administração pública? Sim, eles respondem, desde que dentro dos parâmetros constitucionais que limitam a atuação do Estado e em sintonia com o princípio da legalidade, no que diz respeito à licitação e às formas de utilização dos bens públicos.

Um bom exemplo de terceirização para aplicação na esfera municipal, justifica-se quando o município deve abster-se de investimentos em máquinas ou custeio para aquelas atividades que exigem grande volume de capital e onde o setor privado, pode ser parceiro nos custos, riscos e receitas. $E$ também onde a obsolescência das máquinas é muito rápida e o custo de atualização é alto, como a informática.

Já no capítulo quarto, introduz-se $\varrho$ papel que o consultor deve assumir no processo de terceirização. O profissional de consultoria atuaria na implantação da cultura da terceirização, após a consecução desse objetivo deve afastar-se da participação ativa para alçar-se à condição de auditar o processo. Assim, são pré-requisitos para terceirizar: o mapeamento do que deve e pode ser terceirizado, comparação de custos e qualidade, eleição do prestador de serviços ou fornecedor.

Como foi apontado na apresentação do livro, a parte legal é a mais impeditiva do processo de terceirização, portanto o objetivo dos capítulos quinto, sexto e sétimo é desvendar essa questão, salientando que a terceirização deve contemplar os princípios jurídicos, atentando para as disposições do direito e do mundo dos negócios, além dos aspectos inerentes à organização. $O$ primeiro cuidado a ser tomado é na elaboração do contrato de parceria; os autores analisam o conteúdo de um contrato como um encontro de vontades, na busca da modernidade, qualidade, produtividade, competitividade. A questão do envolvimento do sindicalismo foi abordada no sentido de esclarecer que a terceirização "correta", sob o ponto de vista legal, não traz prejuízos ao trabalhador. A pulverização da atividade sindical na opinião dos autores, é resultado do Decreto 90.922/85 que regulamenta a lei $5524 / 68$ e cria a figura do técnico de nível médio*. Enfim, é observada a inexistência no ordenamento jurídico brasileiro de regulamentação específica para a terceirização, mesmo assim, esta não contraria os dispositivos legais.

O oitavo capítulo insere o conceito de quarteirização, ou seja, a terceirização elevada ao expoente da vanguarda, com a contratação de uma empresa especializada, que se encarrega de gerenciar parcerias. Com o intuito de demonstrar o alcance da idéia da terceirização, o capítulo nono constata a popularização do termo através do destaque dado pela imprensa recentemente, o que por si só já reforça a discussão do seu processo como alternativa de flexibilidade empresarial.

A maior contribuição do livro se refere a não se limitar à aplicação de modelos contidos em manuais, o processo de terceirização vai além do estabelecimento de regras, a terceirização, portanto é sempre única e dinâmica, exigindo planejamento profissional especializado. $\Delta$

(') Lei que permite técnicos de nível médio, industriais ou agricolas, num mesmo sindicato - o Sintec - ou seja, reúne categorias distintas com reivindicações distintas, num mesmo sindicato. 